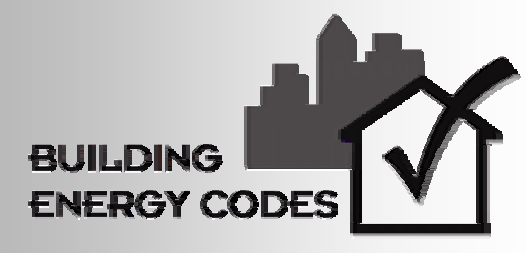

PNNL-14235

\title{
Understanding Building Energy Codes and Standards
}

\author{
R. Bartlett \\ M.A. Halverson \\ D.L. Shankle
}

March 2003

Prepared for the U.S. Department of Energy under Contract DE-AC06-76RL01830 


\section{DISCLAIMER}

This report was prepared as an account of work sponsored by an agency of the United States Government. Neither the United States Government nor any agency thereof, nor Battelle Memorial Institute, nor any of their employees, makes any warranty, express or implied, or assumes any legal liability or responsibility for the accuracy, completeness, or usefulness of any information, apparatus, product, or process disclosed, or process disclosed, or represents that its use would infringe privately owned rights. Reference herein to any specific commercial product, process, or service by trade name, trademark, manufacturer, or otherwise does not necessarily constitute or imply its endorsement, recommendation, or favoring by the United States Government or any agency thereof, or Battelle Memorial Institute. The views and opinions of authors expressed herein do not necessarily state or reflect those of the United States Government or any agency thereof.

\section{PACIFIC NORTHEST NATIONAL LABORATORY \\ operated by \\ BATTELLE for the \\ UNITED STATES DEPARTMENT OF ENERGY Under Contract DE-AC06-76RL01830}

Printed in the United States of America

Available to DOE and DOE contractors from the

Office of Scientific and Technical Information,

P.O. Box 62, Oak Ridge, TN 37831-0062;

ph: (865) 576-8401

fax: (865) 576-5728

email: reports@adonis.osti.gov

Available to the public from the National Technical Information Service, U.S. Department of Commerce, 5285 Port Royal Rd., Springfield, VA 22161 ph: (800) 553-6847 fax: (703) 605-6900

email: orders@ntis.fedworld.gov

Online ordering: http://www.ntis.gov/ordering.htm 


\title{
Understanding Building Energy Codes and Standards
}

\author{
R. Bartlett \\ M.A. Halverson \\ D.L. Shankle
}

March 2003

Prepared for

the U.S. Department of Energy

under Contract DE-AC06-76RL01830

Pacific Northwest National Laboratory

Richland, Washington 99352 


\section{Understanding Building Energy Codes and Standards}

\section{The ICC Codes}

The International Code Council publishes a variety of model codes in addition to the IECC:

- International Mechanical Code

- International Plumbing Code

- International Fire Code

- International Electrical Code

- International Fuel Gas Code

- International Private Sewage Code

- International Property Maintenance Code

- International Zoning Code

- International Residential Code (IRC). A complete residential building code, containing more than just energy provisions. Includes the simple, prescriptive energy provisions for residential buildings from the IECC. (The IECC includes many other compliance paths besides the simple prescriptive path found in the IRC.)

- International Building Code. A complete building code for residential and commercial buildings, containing more than just energy provisions.
Energy-efficient buildings offer energy, economic, and environmental benefits. They reduce energy expenditures and environmental pollutants. They also create economic opportunities for business and industry by promoting new energyefficient technologies.

Unfortunately, the marketplace does not guarantee energy-efficient design and construction. Owners of commercial buildings generally pass on energy costs to consumers or tenants, eliminating any incentive for energy-efficient design and construction. Homebuyers often are motivated more by up-front costs than operating costs.

Energy codes and standards play a vital role by setting minimum requirements for energy-efficient design and construction. They outline uniform requirements for new buildings as well as additions and renovations.

\section{The Difference Between Energy Codes, Energy Standards, and the Model Energy Code}

Energy codes - specify how buildings must be constructed or perform, and are written in mandatory, enforceable language. States or local governments adopt and enforce energy codes for their jurisdictions.

Energy standards - describe how buildings should be constructed to save energy cost-effectively. They are published by national organizations such as the American Society of Heating, Refrigerating, and Air-Conditioning Engineers (ASHRAE). They are not mandatory, but serve as national recommendations, with some variation for regional climate. States and local governments frequently use energy standards as the technical basis for developing their energy codes. Some energy standards are written in mandatory, enforceable language, making it easy for jurisdictions to incorporate the provisions of the energy standards directly into their laws or regulations.

The International Code Council (ICC) publishes and maintains the International Energy Conservation Code (IECC), which is a model energy code that makes allowances for different climate zones. Because it is written in mandatory, enforceable language, state and local jurisdictions can easily adopt the model as their energy code. Before adopting the IECC, state and local governments often make changes to reflect regional building practices.

Table 1 provides an overview of energy standards and the model energy code. 
Table 1. Overview of National Energy Standards and the Model Energy Code

\section{DOE Monitors the Model Energy Code Federal law requires the U.S. Department of Energy (DOE) to determine whether revisions to the residential portion of the IECC would improve energy efficiency in the nation's residential buildings and whether revisions to ASHRAE/IESNA/ANSI Standard 90.1 would improve energy efficiency in the nation's commercial buildings.}

When DOE determines that a revision would improve energy efficiency, each state has two years to review the energy provisions of its residential or commercial building code. For residential buildings, a state has the option of revising its residential code to meet or exceed the residential portion of the IECC. For commercial buildings, a state is required to update its commercial code to meet or exceed the provisions of Standard 90.1 .

\begin{tabular}{|c|c|c|c|c|}
\hline Title & Type & $\begin{array}{c}\text { Sponsoring } \\
\text { Organization(s) }\end{array}$ & Description & $\begin{array}{c}\text { Commonly } \\
\text { Used } \\
\text { Versions }\end{array}$ \\
\hline $\begin{array}{l}\text { International Energy } \\
\text { Conservation Code } \\
\text { (IECC) }\end{array}$ & $\begin{array}{l}\text { Model } \\
\text { Energy Code }\end{array}$ & ICC & $\begin{array}{l}\text { Applies to } \\
\text { residential and } \\
\text { commercial } \\
\text { buildings. } \\
\text { Written in } \\
\text { mandatory, } \\
\text { enforceable } \\
\text { language. }\end{array}$ & $\begin{array}{l}1998 \text { IECC } \\
2000 \text { IECC }\end{array}$ \\
\hline $\begin{array}{l}\text { ASHRAE/IESNA/AN } \\
\text { SI Standard 90.1: } \\
\text { Energy-Efficient } \\
\text { Design of New } \\
\text { Buildings Except } \\
\text { Low-Rise Residential } \\
\text { Buildings }\end{array}$ & $\begin{array}{l}\text { Energy } \\
\text { Standard }\end{array}$ & $\begin{array}{l}\text { ASHRAE, together } \\
\text { with the Illuminating } \\
\text { Engineering Society } \\
\text { of North America } \\
\text { (IESNA) and the } \\
\text { American National } \\
\text { Standards Institute } \\
\text { (ANSI) }\end{array}$ & $\begin{array}{l}\text { Applies to all } \\
\text { buildings except } \\
\text { residential } \\
\text { buildings with } \\
\text { three stories or } \\
\text { less. }\end{array}$ & $\begin{array}{l}90.1-1989 \\
90.1-1999^{(a)}\end{array}$ \\
\hline $\begin{array}{l}\text { ASHRAE Standard } \\
90.2 \text { Energy-Efficient } \\
\text { Design of New Low- } \\
\text { Rise Residential } \\
\text { Buildings }\end{array}$ & $\begin{array}{l}\text { Energy } \\
\text { Standard }\end{array}$ & ASHRAE & $\begin{array}{l}\text { Applies to } \\
\text { residential } \\
\text { buildings with } \\
\text { three stories or } \\
\text { less. }\end{array}$ & $\begin{array}{l}90.2-1993 \\
90.2-2001\end{array}$ \\
\hline
\end{tabular}

\section{How Are Energy Standards Developed and Revised?}

Standards 90.1 and 90.2 are developed and revised through voluntary consensus and public hearing processes that are critical to widespread support for their adoption.

\section{Who Is Involved?}

ASHRAE works with other standards organizations, such as the IESNA, ANSI, American Society of Testing and Materials (ASTM), Air Conditioning and Refrigeration Institute (ARI), and Underwriters Laboratories (UL). The voluntary consensus process also includes representation from:

- The design community, including architects, lighting, and mechanical designers;

- Members of the enforcement community, including building code officials, representatives of code organizations, and state regulatory agencies; 
- Building owners and operators;

- Industry and manufacturers;

- Utility companies; and

- Representatives from the Department of Energy, Pacific Northwest National Lab, energy advocacy groups, and the academic community.

\section{How Does the Process Work?}

Standards 90.1 and 90.2 are both on continuous maintenance and are maintained by separate Standing Standards Project Committees. Committee membership varies from 10 to 60 voting members. Committee membership includes representatives from the list above to ensure balance among all interest categories.

After the committee proposes revisions to the standard, it undergoes public review and comment. The committee usually incorporates non-substantive changes into the standard without another review. Substantive changes require additional public review. Occasionally, mediation is necessary to resolve differing views.

When a majority of the parties substantially agree (this is known as consensus), the revised standard is submitted for approval to the ASHRAE Board of Directors. Those not in agreement with the decision may appeal to the Board. If an appeal is upheld, further revision, public comment, and resolution occur. If the Board denies the appeal, publication of the revised standard would then proceed.

The entire process can take as little as two years or up to 10 years.

\section{What's the Timing of Revisions to Standards 90.1 and}

\section{2?}

Standards 90.1 and 90.2 are automatically revised and published every three years. However, anyone may propose a revision at any time. Approved interim revisions (called addenda) are posted on the ASHRAE website and are included in the next published version.

Key activities relating to revisions, including responding to public comments, typically occur during one of ASHRAE's annual (June) or mid-winter (January) meetings. Public review of standards commonly occurs two to four months after one of these meetings. 


\section{How Are Model Energy Codes Developed and Revised?}

The most recent model energy codes are the 1998 IECC and the 2000 IECC.

These are developed and published by the International Code Council through an open public-hearing process. Prior to 1998, the IECC was known as the Council of American Building Officials Model Energy Code (MEC).

\section{Who Is Involved?}

The IECC Code Development Committee typically comprises of seven to 11 individuals appointed by the ICC. Most, but not all, committee members are code officials. They may or may not be members of the ICC.

\section{How Does the Process Work?}

Anyone may suggest a revision to the IECC by requesting a code change proposal from the committee and preparing a recommended change and substantiation. The committee publishes proposed changes and distributes them for review. This occurs about six weeks prior to an open public hearing.

At the public hearing, the committee receives testimony and then votes to approve, deny, or revise each change. The committee publishes its results.

Those wishing to have a proposed change reconsidered may submit a challenge to the committee's recommended action. Proponents and opponents present additional information at a second public hearing, followed by a vote by the full ICC membership. This outcome may be appealed to the ICC Board of Directors.

\section{What's the Timing of the Process?}

The IECC is revised on an annual cycle. However, full publication of the document occurs every third year, with supplements issued in the interim years.

When developing and adopting their own energy codes, states and local governments typically adopt the full-published IECC. By specifically adopting the supplements as well, state and local governments ensure that their energy codes include important additions and clarifications to the IECC.

\section{Adoption of Energy Codes on the State and Local Level}

Before adopting or revising an energy code, states and local governments often assemble an advisory body comprising representatives of the design, building 
construction, and enforcement communities. This body determines which (if any) energy standards and model energy codes should be adopted. The group also considers the need to modify energy standards and model energy codes to account for local preferences and construction practices. The body also may serve as a source of information during the adoption process.

\section{Overview of the Adoption Process}

The adoption process generally includes the following steps:

- Change is initiated by a legislative or regulatory agency with authority to promulgate energy codes. Interested or affected parties also may initiate change. An advisory body typically is convened. The proposed energy code is developed.

- The proposal undergoes a legislative or public review process. Public review options include publishing a notice in key publications, filing notices of intent, or holding public hearings. Interested and affected parties are invited to submit written or oral comments.

- The results of the review process are incorporated into the proposal, and the final legislation or regulation is prepared for approval.

- The approving authority reviews the legislation or regulation. Revisions may be submitted to the designated authority for final approval or for filing.

- After being filed or approved, the code is put into effect, usually on some specified future date. This grace period allows those regulated to become familiar with any new requirements. The period between adoption and effective date typically varies from 30 days to six months.

Details of the adoption process vary depending on whether the energy code is adopted by legislation, regulation, or a local government. Each is discussed below.

\section{Adoption Through Legislation}

State legislation rarely includes the complete text of an energy standard or model energy code. More commonly, legislation references an energy standard or model energy code that is already published. The legislation often adds administrative provisions addressing enforcement, updating, variances, and authority.

Another common approach is to use legislation to delegate authority to an agency, council, or committee. The delegated authority is empowered to develop 


\section{City of Chicago Adopts a Modified IECC}

In 2001, the City of Chicago adopted the first building energy code in Illinois, which is a home-rule state. Chicago's building energy code, which took effect September 2002, is a modified version of the 2000 International Energy Conservation Code. The city adopted the code to help address local issues such as escalating natural gas prices, reliability of power supplies, and noncompliance with the U.S. Environmental Protection Agency air quality regulations. Chicago's energy code has paved the way for other large jurisdictions in Illinois to adopt similar codes and has encouraged a current effort to pursue adoption of a statewide energy code. and adopt regulations governing energy-related aspects of building design and construction. Such regulations are discussed in the next section.

Some states adopt the administrative provisions of the energy code by legislation and the technical provisions by regulation, or vice versa.

\section{Adoption Through Regulation}

A key factor in a state's ability to regulate the energy-related aspects of design and construction is the extent to which the state has authority over adoption, administration, implementation, and enforcement of building construction regulations. In most states, a single state agency has such authority. In some states, no such authority exists. If multiple state agencies, committees, or councils are involved, the authority is diluted.

When a state agency, council, or committee has authority to adopt regulations, it must follow requirements outlined in the legislation that enables development, revisions, and adoption of the regulations. The technical provisions of the regulations may be unique to the state, or the regulations may adopt, by reference, national energy standards or a model energy code. When a state adopts regulations, it typically includes its own administrative provisions within the regulations.

\section{Adoption by Local Government}

If a state has limited authority to adopt an energy code (a "home rule" state ${ }^{(a)}$ ), units of local government have the option to assume that responsibility. Local governments also can adopt standards or codes that are more stringent than the state's.

A local government's municipal code typically includes a title or provision covering building construction, under which energy provisions can be adopted.

Most local governments adopt a model energy code by reference. They apply administrative provisions from other building construction regulations to implementation and enforcement of the energy code.

\section{Timing the Adoption and Revision of State and Local Codes}

Most states adopt or revise energy codes in concert with the publication of a new edition of a national energy standard or model energy code. This may occur

(a) In the energy codes and standards arena, home rule means the state cannot interfere or control on the local level. 
either through a regulatory process or automatically because state regulation or legislation refers to "the most recent edition."

Adoption also can be tied to the publication date of an energy standard or model energy code e.g., "This regulation shall take effect one month from publication of the adopted model energy code."

\section{Implementation of Energy Codes on the State and Local Level}

During implementation, the adopting jurisdiction(s) must prepare building officials to enforce the energy code and prepare the building construction community to comply with it. It is important for all stakeholders to know that a new code is coming and understand what is required. Many states or jurisdictions start this education process several years in advance of an energy code change - often before adoption itself. The more publicity and training on the new code, the more it will be accepted and used.

Communication and information exchange should occur:

- Between the code-adopting bodies and code-enforcing bodies;

- Between the code-adopting bodies and the building construction community;

- Between the code-enforcing bodies and the building construction community;

- Within the building construction community and code-enforcing bodies.

Training is critical. To be effective, training must cater to the specific needs of building officials, architects, designers, engineers, manufacturers, builders and contractors, and building owners. Training for specific stakeholders can be provided or sponsored by the following:

- State energy offices and agencies

- Universities and community colleges

- Professional organizations and societies

- Utilities

- Trade associations

- National or regional code organizations

- Others, such as the Southface Energy Institute (www.southface.org) or product distributors.

The Department of Energy, the ICC, ASHRAE and other codes organizations can supply tools and materials to make implementation and training easier for states and local jurisdictions. 


\section{Enforcement of Energy Codes on the State and Local Level}

Enforcement ensures compliance with an energy code and is critical to securing energy savings. Enforcement strategies vary according to a state or local government's regulatory authority, resources, and manpower. Enforcement can include all or some of the following activities:

- Review of plans

- Review of products, materials, and equipment specifications

- Review of tests, certification reports, and product listings

- Review of supporting calculations

- Inspection of the building and its systems during construction

- Evaluation of materials substituted in the field

- Inspection immediately prior to occupancy

Sometimes a state or local government has no enforcement authority. The courts then address enforcement, if and when legal action is sought by a building owner against a designer or contractor.

\section{State Enforcement}

State enforcement is a common approach in smaller states, in rural jurisdictions that have no code officials, and for state-owned or financed construction.

Enforcement by a single state agency usually is more uniform than enforcement conducted by several local agencies. Plan review is generally performed by one office. Although there may be numerous state field inspectors, they are bound under one organization. This arrangement benefits the building construction community by offering a single point of contact. However, if state resources are limited, plan reviews and construction inspections may not be performed as thoroughly as warranted.

\section{Local Enforcement}

Local enforcement agencies are closer to the construction site and in more direct contact with the design and construction community. This offers the potential for more regular enforcement during design and construction.

However, local jurisdictions may lack sufficient resources to support enforcement. Because jurisdictions vary, local enforcement may lead to some noncompliance across a state. Compliance is enhanced when a state code agency actively supports local governments in their efforts to enforce the state code. 
Some states allow local jurisdictions to petition to conduct enforcement activities that are usually the responsibility of the state. This strategy offers the advantages associated with state enforcement, recognizes those local governments with equivalent enforcement capabilities, and helps ensure comparable levels of compliance. Continued state oversight is necessary to ensure a consistent level of enforcement by local jurisdictions. A hybrid approach might involve the state conducting the plan review, and the local authority conducting the construction inspection.

\section{Voluntary Energy-Efficiency Programs}

Voluntary programs encourage a level of energy efficiency above code. They can help motivate consumers to recognize the value of energy efficiency. Examples include:

- Home energy rating systems. Also known as HERS, these compare the energy efficiency of a home to a computer-simulated reference house. The rating involves analysis of the home's construction plans and at least one on-site inspection. This information is used to estimate the home's annual energy costs and give the home a rating between 0 and 100. The higher the score, the more efficient the home.

- Energy StaR ${ }^{\circledR}$. The U.S. Environmental Protection Agency outlines criteria for ENERGY STAR certification of homes and commercial buildings. ENERGY STAR homes are typically 30 percent more energy efficient than average minimum energy codes. For more information, go to www.energystar.gov.

- Utility, government, and other programs. Utilities, state and local governments, and other organizations often sponsor programs that qualify buildings based on certain standards. Examples include Good Cents and the U.S. Green Building Council's Leadership in Energy \& Environmental Design $\left(\mathrm{LEED}^{\mathrm{TM}}\right)$.

\section{DOE Support}

The Department of Energy's Building Energy Codes Program (BECP) supports states and local governments in their efforts to implement and enforce building energy codes. This support includes:

- Developing and distributing easy-to-use compliance tools and materials; 
- Providing financial and technical assistance to help adopt, implement, and enforce building energy codes;

- Participating in the development of model energy codes and energy standards; and

- Providing information on compliance products and training, and energy code-related news.

For more information on BECP products and services, visit the BECP website at www.energycodes.gov. 


\section{Standards Organizations and Code Organizations}

American Society of Heating, Refrigerating, and AirConditioning Engineers (ASHRAE)

1791 Tullie Circle NE

Atlanta, GA 30329

(404) 636-8400

www.ashrae.org

Building Officials and Code Administrators International (BOCA)

4051 West Flossmoor Road

Country Club Hills, IL 60478-5795

(800) 214-4321

www.bocai.org

\section{International Code Council (ICC)}

5203 Leesburg Pike, Suite 708

Falls Church, VA 22041

(703) 931-4533

www.intlcode.org

\section{International Conference of Building Officials (ICBO)}

5360 South Workman Mill Road

Whittier, CA 90601-2298

(562) 699-0541 or (800) 284-4406

www.icbo.org

\section{Southern Building Code Congress International (SBCCI)}

900 Montclair Road

Birmingham, AL 35213-1206

(205) 591-1853 or (888) 44-SBCCI

www.sbcci.org

\section{Building Energy Codes Program}

\section{U.S. Department of Energy}

www.energycodes.gov 